\title{
The Role of Transformational and Transactional Leadership in Creating, Sharing and Exploiting Organizational Knowledge
}

\section{Authors: Scott E. Bryant}

This is a postprint of an article that originally appeared in Journal of Leadership and Organizational Studies n January 2003. The final version can be found at http://dx.doi.org/10.1177/107179190300900403.

Bryant, S. E. "The Role of Transformational and Transactional Leadership in Creating, Sharing and Exploiting Organizational Knowledge." Journal of Leadership and Organizational Studies 9, no. 4 (January 1, 2003): 32-44. doi: 10.1177/107179190300900403. 


\title{
The Role of Transformational and Transactional Leadership in Creating, Sharing and Exploiting Organizational Knowledge
}

\author{
Scott E. Bryant \\ Montana State University \\ Bozeman, MT
}

Strategy scholars have argued that managing knowledge effectively can provide firms with sustainable competitive advantages. Leaders are central to the process of managing knowledge effectively. Managing knowledge includes three key processes: creating, sharing, and exploiting knowledge. Leaders are central to each of these processes at multiple levels of the firm. Examining the role of leadership in converting knowledge into competitive advantages is important to our understanding of leaders and organizations. Transformational leadership may be more effective at creating and sharing knowledge at the individual and group levels, while transactional leadership is more effective at exploiting knowledge at the organizational level. This paper begins to integrate the transformational leadership literature with the organizational knowledge literature.

Key Words: Knowledge Creation, Sharing and Exploiting, Transformational Leadership, Transactional Leadership, Strategy

Leaders play a central role in the process of managing organizational knowledge. Leaders provide vision, motivation, systems and structures at all levels of the organization that facilitate the conversion of knowledge into competitive advantages. Managing knowledge requires a conscious effort on the part of leaders at all levels of the organization to manage three key knowledge processes: creating, sharing and exploiting knowledge. Transformational leadership theory and transactional leadership theory provide a foundation for understanding how leaders impact the cultivation of knowledge (Bass, 1985; Conger \& Kanungo, 1998; House, 1977; House \& Aditya, 1997). Conger (1999) recently argued that researchers should continue developing transformational and charismatic leadership theory and doing exploratory research in this area. Exploring the role of leadership styles in converting knowledge into competitive advantages is important to our understanding of leaders and organizations.

Strategy scholars have begun to outline a knowledge-based view of the firm, which suggests that managing organizational knowledge effectively can provide firms with a source of sustainable competitive advantage (Boisot, 1998; Glazer, 1998; Grant, 1996; Teece, 1998). These theorists argue that intangible knowledge-based resources, rather than physical and financial resources, provide the key source of a firm's competitive advantage. Effectively leading organizational knowledge processes is essential to achieving and sustaining a competitive advantage.

Leadership styles played a critical role in the inability of Xerox to capitalize on its invention of the first user-friendly personal computer. The researchers in the Xerox Palo Alto Research Center (PARC) developed the first graphical user interface, mouse and menudriven computer-technological advances that made computing accessible to the novice user (Bennis \& Biederman, 1997). The lab's charismatic leader, Bob Taylor, recruited only the very brightest scientists, gave them the freedom to innovate and inspired them to work 
together to solve tremendously complex problems. Researchers at PARC invented new products, obtained multiple patents and pioneered many of the computer technologies we now take for granted. However, because Xerox PARC was not well integrated into the rest of the company, Xerox's top management was skeptical of the inventions the lab developed and didn't see how they fit in with their current copying equipment (Poe, 2000). Xerox lacked a transactional leadership style in the top management team to provide the structure and systems that could capture the knowledge generated in the PARC labs.

Where Xerox failed, Apple succeeded. Steve Jobs visited the PARC facility in 1979 and immediately saw the future of computing in the mouse-driven graphical user interface (Bennis \& Biederman, 1997). Jobs left the PARC labs without any hardware or software but with a vision for how computers should operate. Jobs and his Apple employees were able to convert the innovative PARC ideas into the Macintosh computer, which debuted in 1984, changing the face of computing. Because of Jobs' leadership, Apple created the systems and structures that were able to convert their knowledge into a valuable product. Jobs exhibited both transformational and transactional leadership styles. He used a transformational leadership style to create a vision for the Macintosh and challenge his employees to reach nearly impossible goals. He used a transactional leadership style to create the systems and structures in Apple that allowed the knowledge created at all levels of the organization to be converted into a valuable product-the Macintosh personal computer.

This paper contributes to the existing organizational knowledge and leadership literatures by exploring the impact of transformational and transactional leadership on organizational knowledge. This paper builds on the knowledge-based view of the firm (Boisot, 1998; Grant, 1996; Teece, 1998) as a foundation for understanding why managing knowledge helps firms create sustainable competitive advantages. It then explores the connection between leadership and three key organizational knowledge processes - creating, sharing and exploiting knowledge--and suggests that firms can use both transformational and transactional leadership styles to effectively manage knowledge. Several propositions connect leadership styles with organizational knowledge processes.

\section{Managing Organizational Knowledge}

The knowledge-based view of the firm builds on the resource-based view of the firm, which suggests that firms' competitive advantages stem primarily from internal resources and capabilities (Barney, 1995; Wernerfelt, 1984; Penrose, 1959). Grant (1996), Teece (1998) and Boisot (1998) provide the foundations for a knowledge-based view of the firm and argue that knowledge is the key resource capable of creating sustainable competitive advantages. Knowledge resources are an especially valuable category of resources and meet Barney's (1991) criteria for resources capable of providing sustainable competitive advantages: valuable, rare, inimitable, nonsubstitutable (Edvinsson and Malone, 1997). Knowledge resources and capabilities include worker know-how, product designs, customer knowledge and efficient processes (Boisot, 1998; Grant, 1996; Teece, 1998; Davenport \& Prusak, 1997). Organizations that manage their knowledge more effectively than their competitors will be able to achieve competitive advantages (Boisot, 1998).

If knowledge is a key organizational resource capable of creating a sustainable competitive advantage, then it is important to examine how firms manage knowledge. First it is important to define organizational knowledge and then explore three fundamental knowledge processes: creating, sharing and exploiting knowledge.

\section{Defining Organizational Knowledge}

Organizational knowledge includes all the tacit and explicit knowledge that individuals possess about products, systems and processes and the explicit knowledge codified in manuals, databases and information systems. Organizational knowledge also includes the tacit knowledge that is shared collectively in the firm in the form of routines, culture and know-how embedded in social processes (Nahapiet \& Ghoshal, 1998; Grant, 1996; Nonaka \& Takeuchi, 1995). There are several key 
organizational knowledge dimensions to consider: tacit and explicit (Polanyi, 1966; Nonaka, 1991; Boisot, 1998); individual and social (Spender, 1996; McEvily, et al, 2000); public and private (Matusik \& Hill, 1998); and the nature of knowledge at multiple levels of the firm (Crossan, Lane and White, 1999).

Knowledge is held by individuals but expressed in regularities in which members cooperate in a social community (i.e., group, organization or network) (Kogut \& Zander, 1992). Organizational knowledge does not completely change when someone comes to the firm or leaves. Knowledge is embedded in the social networks, systems and relationships in the firm. Firms learn new skills by recombining their current capabilities. Knowledge growth occurs by building on the social relationships that currently exist in the firm (Kogut \& Zander, 1992).

\section{Knowledge Creation and Sharing}

Nonaka \& Takeuchi (1995) describe how firms create new knowledge through four primary modes that involve the interaction of tacit and explicit knowledge: socialization, externalization, internalization, and combination. Socialization is the process of sharing one's experience with another, thereby creating tacit knowledge in the form of mental models and technical skills. Externalization converts tacit knowledge into explicit concepts. Firms do this by using metaphors, analogies, concepts or models. Knowledge created in formal educational settings such as in universities and in MBA programs fits in this category. Internalization involves turning explicit knowledge into tacit knowledge. Knowledge that has been generated by others is absorbed by another individual and internalized. The Combination process creates a new form of knowledge by combining two sources of explicit knowledge. For example, several reports may be integrated into a more succinct summary report and entered into a database or knowledge base. This process changes the form of the knowledge but it remains in explicit form.

\section{The 4-i Organizational Knowledge Framework}

The organizational learning literature provides a bridge between the cultivation of knowledge and the organization's strategy. Significant theoretical work has examined organizational learning (Bontis, 1999; Dodgson, 1993; Huber, 1991; Senge, 1990a; Senge, 1990b). Recent work by Crossan, Lane and White (1999) has begun to pull together the disparate streams of organizational learning literature into a more cohesive construct, centered on strategic renewal. Organizational learning encompasses both cognitive processes and individual behaviors that add new knowledge to firms and allow managers to act based on that knowledge (Crossan, et al., 1999).

Crossan et al.'s (1999) 4-i framework integrates multiple levels of analysis (individual, group, and organization) with the dynamic tension created by knowledge exploration and exploitation (Levinthal \& March, 1993). This results in four key processes underlying organizational knowledge: Intuiting, Interpreting, Integrating and Institutionalizing. Intuiting is the individual process of converting personal experiences, thoughts and images into insights or new ways of viewing things. These insights are converted into language and metaphor in the Interpreting process, allowing one individual to communicate with another. Groups combine these individual insights and metaphors in the Integrating process into interactive systems and cognitive maps. Organizations Institutionalize knowledge by routinizing actions and turning knowledge into standard operating rules and procedures. This process results in an organizational knowledge system or set of systems.

If we combine Nonaka and Takeuchi's (1995) knowledge creation model with Crossan, et al.'s (1999) strategic learning model, we create a dynamic multilevel model for managing organizational knowledge. At the individual level knowledge is converted from tacit to explicit and from explicit to tacit through a process of intuition and interpretation. At the group level knowledge is integrated through a socialization process. Ideas and metaphors are shared and converted into shared cognitive maps, much of which remains tacit. These maps 
are then transferred through modeling as well as verbal interaction. At the organizational level knowledge is combined into new patterns and then institutionalized into routines, rules and procedures. Combined knowledge is explicit and can be entered into a knowledge system that can then be accessed by individuals and groups. Combining the 4-i framework with Nonaka and Takeuchi's (1995) model of tacit and explicit knowledge provides us with a richer understanding of how knowledge is cultivated at each level of the organization.

Nonaka \& Takeuchi (1995) provide four modes of knowledge creation, and Crossan \& colleagues (1999) provide four learning processes that operate at each level of the organization and impact strategy. We can examine the role of leadership styles in managing knowledge creation, sharing and exploiting processes at different levels of the firm (individual, group, and organization).

\section{Creating Knowledge}

Leaders provide the context in which workers create knowledge and can influence the levels of creativity in the organization (Mumford, Whetzel \& Reiter-Palmon, 1997; Redmond, Mumford \& Teach, 1993). Leaders have direct control over what activities are rewarded, what behaviors are encouraged and how work will be valued in the organization. These factors all influence workers' motivation and ability to develop new knowledge. Individuals develop new ideas and new knowledge during the creation process by converting their personal experiences and images into personal insights (Nonaka, 1991). These insights can then be shared with others on the team.

For example, usability engineers in a large northwest software firm design mini research projects that assess the ease of use of software features and Web site features. The usability engineers continually improve the research process by making it more efficient and effective. They generate new ideas each time they conduct a study. When they share their new ideas with each other, it allows them all to do their jobs more effectively.

\section{Sharing Knowledge}

Leaders encourage workers to share their ideas by creating a climate that is receptive to new ideas. In the software usability engineering group referred to above, the team's manager encourages the engineers to share the insights they gain while conducting research projects. They meet together weekly to discuss their projects and offer each other solutions to problems. However, because they are not physically located next to each other, it requires extra effort on the part of the leader and the engineers to facilitate the knowledge sharing process. Workers may be more likely to share knowledge when they are praised by managers, have knowledge sharing as part of their performance evaluations and are provided financial and non-financial rewards for sharing. Team leaders have control over praise and performance evaluations, but require support from higher levels of management to provide raises, bonuses and other rewards for sharing behaviors.

\section{Exploiting Knowledge}

Organizations that have systems in place to convert creative ideas into valuable products and services are better able to exploit their knowledge. Schumpeter (1950) provides a valuable distinction between inventions and innovations. Inventions are both the good ideas that lead to new products and services as well as the products and services themselves. However, inventions only become innovations when organizations convert them into products and services that customers value. Thus an idea is exploited when it is converted into a product or service that generates revenue for the firm. Boisot (1998) describes the exploitation of knowledge as the process of converting knowledge into revenue-generating products and services. For example, the research findings that the usability engineers report to the program managers are used to change features and improve the ease of use, and therefore, the quality of software programs and Web sites. This knowledge is captured in the form of an email and in some cases is entered into an electronic knowledge base that is made available to the rest of the firm.

A large northwest software firm that maintains databases for tracking all known 
problems or "bugs" in the software provides another example. Workers at all levels and all departments in the organization can post a bug to the database. In order to keep the database as effective and efficient as possible, workers follow strict rules before posting a bug to the database. The most important rule is to search the database first to see if someone else has already discovered the bug. If not, then the worker writes it up and passes it on to a supervisor. This prevents redundant bugs from being entered into the system and slowing it down. The bug will then be reviewed and entered into the database, making it available to all parts of the organization including technical support, software testing, software engineering, marketing and program management.

The organizational knowledge processes recognize people's need to be encouraged and attended to in order to foster knowledge creation, sharing and exploitation. Firms that are able to more effectively manage this process can achieve competitive advantages.

\section{Transformational And Transactional Leadership}

Transformational and charismatic leadership theories provide a useful lens for understanding how leaders impact the management of organizational knowledge. Though there are differences between the transformational and charismatic leadership theories, scholars are now viewing them as sharing much in common and referring to this body of work as the "new leadership" theory (Hunt \& Conger, 1999) or "neo-charismatic" leadership theory (Fiol, Harris, \& House, 1999).

Transformational leaders are active leaders that have four distinguishing characteristics: charisma, inspiration, intellectual stimulation and individualized consideration (Bass, 1985; Conger, 1999). Charisma is the extent of pride, faith and respect leaders encourage their workers to have in themselves, their leaders and their organizations. Inspiration is the ability to motivate followers largely through communication of high expectations. Intellectual stimulation is the frequency with which leaders encourage employees to be innovative in their problem solving and solutions. Finally, individualized consideration is the degree of personal attention and encouragement of selfdevelopment a leader imparts to the employees (Bass, 1985; Bass, 1990). Transformational leaders devote significant energy to leading and respect the gifts and abilities of their workers.

The transformational leadership style was introduced by Burns (1978) and extensively researched by Bass and his associates (1985). The charismatic leadership style shares much in common with Bass's transformational leadership construct and has been developed largely by House (1977), House and associates (1991), Conger (1999) and Conger \& Kanungo (1998). Sashkin (1988) has done related work on visionary leadership that highlights the visionary nature of top leaders.

Over thirty recent leadership studies in a wide variety of organizations have examined the impact of transformational and charismatic leaders on subjects in a wide variety of settings, including corporations, schools and military units (Conger \& Kanungo, 1998; House \& Aditya, 1997; Fiol, et al, 1999; Podsakoff, McKenzie and Bommer, 1996; Lowe, et al, 1996; Keller, 1992). Across all these studies, researchers found that transformational and charismatic leadership styles "result in a highlevel of follower motivation and commitment and well-above-average organizational performance, especially under conditions of crises or uncertainty" (House \& Aditya, 1997: 441; Lowe, et al, 1996). With the ubiquity of the Internet and the growth of virtual work teams, researchers have begun to examine the impact of transformational leadership on knowledge creation in these computer-mediated groups (Sosik, 1997).

Bass (1985) suggested that under certain conditions employees could rise above their own self-interests and give extra effort in order to achieve the organization's mission. He argued that transformational leaders are able to elicit this extraordinary performance. Transformational leaders can be defined both by their effect on followers and their behaviors that seem to motivate exceptional performance (Conger \& Kanungo, 1998; Bass, 1985).

Several leadership scholars have argued that Bass's model is incomplete because it does not properly account for organizational context factors that will significantly impact the effectiveness of the transformational leader 
(Conger \& Kanungo, 1998; Conger, 1999; Yukl \& Howell, 1999). These authors add sensitivity to the environment as a key dimension of the charismatic leader. This element is important because charismatic leaders are generally quite shrewd at evaluating the climate of the team and the organization and modifying their plans accordingly.

Several elements of transformational leadership theory fit well with managing knowledge. Employees are more productive when they have the freedom to create new ideas, share those ideas with coworkers and test out their new ideas (Sosik, 1997). Transformational leaders create an atmosphere conducive to knowledge creation, sharing and exploitation. In particular, by using charisma, encouraging intellectual development and by paying individual attention to workers, transformational leaders motivate their workers to create and share knowledge. Transformational leaders are able to attract talented individuals by clearly articulating a challenging vision and strategic goals for the organization (Conger \& Kanungo, 1998). Having bright, talented people is necessary, but not sufficient to effectively facilitate the creating, sharing and exploiting of knowledge. Transformational leaders inspire workers on to higher levels of innovation and effectiveness.

Transformational leaders may be able to generate higher levels of innovation from all workers. However, knowledge intensive workers, such as software programmers and usability engineers, pose a special set of problems that transformational leaders are uniquely able to deal with. First, knowledge workers usually have more expertise than their supervisors (Starbuck, 1992). Second, coworkers are often the best source of new knowledge (Nonaka \& Takeuchi, 1995). Third, knowledge workers tend to be self-motivated and require less direct supervision (Davenport et al., 1996; Miles, et al., 1997). Fourth, the means through which work can be accomplished is less clear than it would be on an assembly line. Knowledge work has a larger tacit dimension. Consequently, it is more difficult to monitor the progress of knowledge workers. Because transformational leaders provide a vision, inspire workers and give individual consideration, their style fits well with the needs of knowledge workers.

\section{Transactional Leadership Theory}

Bass (1985) contrasts transformational leaders with transactional leaders, and Conger \& Kanungo (1998) contrast charismatic leaders with non-charismatic leaders. While transformational leaders inspire exceptional performance, transactional or non-charismatic leaders aspire to achieve solid, consistent performance that meets agreed upon goals. Transactional leaders give rewards and punishments to encourage performance, making the leader/worker relationship essentially an economic transaction (Bass, 1985). Transactional leaders have three primary characteristics. First, transactional leaders work with their team members to develop clear, specific goals and ensure that workers get the reward promised for meeting the goals. Second, they exchange rewards and promises of rewards for worker effort. Finally, transactional leaders are responsive to the immediate self-interests of workers if their needs can be met while getting the work done.

Transactional leadership encourages specific exchanges and a close connection between goals and rewards. Consequently, workers are not motivated to give anything beyond what is clearly specified in their contract. This is especially troubling for knowledge workers for whom it is much more difficult to specify complete job descriptions in advance. Workers may also choose to utilize their excess brain capacity by consulting or starting their own business if they are not challenged and rewarded for extra effort in the firm.

According to Bass (1985) and Conger \& Kanungo (1998) all leaders exhibit characteristics of both transformational and transactional leadership styles. Individual leaders tend to emphasize one of these styles more than the other. Both types of leaders are required to effectively manage knowledge (Conger, 1999). The next section examines the potential impact of these leadership styles on knowledge creating, sharing and exploiting. 


\section{Leadership And Knowledge Model}

Managing organizational knowledge involves managing the knowledge creating, sharing and exploiting processes (Boisot, 1998). Researchers have begun to explore the relationship between transformational leadership and organizational learning processes (Gronn, 1997). Figure 1 illustrates the relationship between leadership, knowledge and performance. Although the model implies a linear process, all learning processes are iterative, with each part feeding back and informing other parts of the process.
In order to effectively manage the creating, sharing and exploiting of knowledge, managers need to address the unique demands of managing knowledge at each level of the organization (Yammarino \& Dubinsky, 1994; Yammarino \& Spangler, 1998). Individual, group and organizational levels may require different leadership styles in order to leverage knowledge into a competitive advantage (Yukl \& Howell, 1999).

Figure 1

Leadership's Effect on Knowledge and Performance

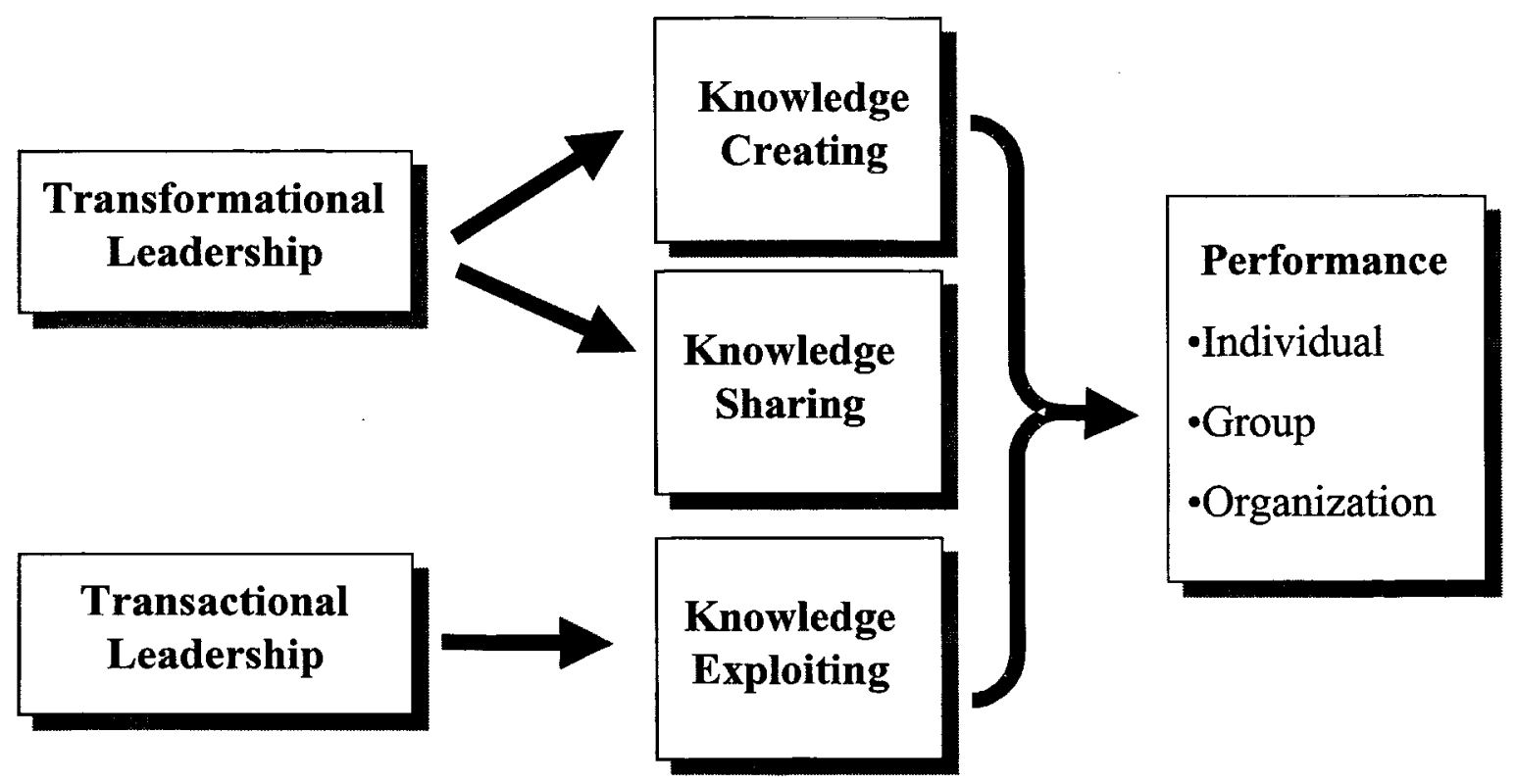

Table 1 provides a summary of the relationship between leadership styles and knowledge at three levels of the firm. The boxes on the diagonal are shaded and indicate the primary knowledge activities that occur at each level of the firm and their corresponding leadership styles. Knowledge creation occurs primarily at the individual level. Knowledge sharing occurs primarily at the group level, although knowledge is also created through group interaction (Nonaka \& Takeuchi, 1995). Knowledge exploiting occurs primarily at the organizational level, since it takes resources from all parts of the organization to convert good ideas into marketable products or services (Boisot, 1998). 
Table 1

Impact of Transformational and Transactional Leadership on Knowledge Cultivation

\begin{tabular}{|c|c|c|c|}
\hline Level & $\begin{array}{l}\text { Knowledge } \\
\text { Creating }\end{array}$ & $\begin{array}{l}\text { Knowledge } \\
\text { Sharing }\end{array}$ & $\begin{array}{l}\text { Knowledge } \\
\text { Exploiting }\end{array}$ \\
\hline Individual & $\begin{array}{l}\text { Transformational } \\
\text { Leadership } \\
\text { - Creativity } \\
\text { - Innovation }\end{array}$ & & \\
\hline Group & $\begin{array}{l}\text { Transformational } \\
\text { Leadership } \\
\text { - Innovation }\end{array}$ & $\begin{array}{l}\text { Transformational } \\
\text { Leadership } \\
\text { - Integration } \\
\text { - Shared mental model }\end{array}$ & $\begin{array}{l}\text { Transactional } \\
\text { Leadership } \\
\text { - Coordination }\end{array}$ \\
\hline Organization & & & $\begin{array}{l}\text { Transactional } \\
\text { Leadership } \\
\text { - } \quad \text { Systems (IS, KM) } \\
\text { - Institutionalization }\end{array}$ \\
\hline
\end{tabular}

\section{Individual Level}

At the individual level knowledge is primarily created. Even though individuals are capable of creating, sharing and exploiting knowledge, they tend to emphasize the creating process when working on their own. Through a process of intuition and creative insight, individuals develop alternatives, solve problems and create new knowledge (Crossan et al., 1999). Transformational leadership provides workers with the motivation, the support and the intellectual stimulation to be innovative. Transformational leaders use charisma to excite and motivate workers to innovate. Through intellectual stimulation from challenging assignments that tap the potential of workers, transformational leaders foster creativity. Finally, by showing individual consideration for workers, transformational leaders encourage workers to share their ideas with the firm. Transformational leaders motivate workers on a day-to-day basis.

Transactional leaders at the individual level tend to over emphasize detailed goals, SOPs, rules and policies. This overemphasis on goals and rules tends to stifle creativity, and the creating of new ideas (Conger and Kanungo, 1998). Transactional leaders do not reward ideas that don't fit with existing plans and goals. For example, software testers use programs that software test engineers develop to find problems or "bugs" in applications, like Adobe PageMaker or Microsoft Word. These testing programs require continuous updating as new features are added and changed in the application. A software tester may discover a better way to test the software and suggest improvements to the testing software. However, transactional leaders would not view "developing new testing programs" as fitting in their goals. Consequently, transactional leaders may discourage the tester from coming up with ideas that are outside the domain of the testers. However, a transformational leader tends to push the boundaries, set stretch goals and provide constant intellectual stimulation. Consequently, a transformational leader would reward the tester for coming up with a valuable new idea and would share the idea with the testing engineers.

In most situations, the transformational leader would encourage more creative solutions and ultimately higher levels of performance. There may be some work situations, such as in highly routinized jobs like housekeeping and assembly line work, in which too much creativity may interfere with effective performance. However, in high technology firms and other knowledge-based firms, generally higher levels of knowledge creation and sharing should correlate with higher levels of performance. This leads to the following propositions.

Proposition 1: A transformational leadership style facilitates higher levels of knowledge creation and sharing at the individual level.

Proposition 2: In most settings higher levels of knowledge creation and sharing 
positively correlate with higher levels of individual performance.

\section{Group Level}

At the group level knowledge is created, shared and exploited, although the primary activity is knowledge sharing. Groups integrate knowledge through interactive systems and create cognitive maps that are shared by the group members (Crossan, et al., 1999). The individual ideas, metaphors and innovations are brought together into a more cohesive and integrated whole. Transformational leadership is essential to facilitating this process. Workers value encouragement and challenges. A transformational leadership style encourages groups to be innovative, solve problems and generate solutions (Bass, 1985). Groups of workers require personal attention and encouragement to develop their talents and ideas. The knowledge integration process is not a clear path with preordained directions. Leaders who are sensitive to the individual needs of groups can respond with an appropriate blend of encouragement and challenge. A transformational leadership style encourages workers to share knowledge with each other.

Transactional leaders at the group level tend to reward structure and conformity to rules. They enforce policies, which can stifle creativity. For example, team leads in a software firm often bring their teams of testers, engineers, developers, etc. together for project updates and brainstorming solutions. Because transactional leaders emphasize meeting goals, they will tend to dampen creative ideas that fall outside the direct scope of the team. Consequently, they stifle innovative solutions that might benefit the firm, but don't fit in the team's goals. This leads to the following propositions.

Proposition 3: A transformational leadership style facilitates higher levels of knowledge creation and sharing in groups.

Proposition 4: Higher levels of knowledge creation and sharing at the group level positively correlate with higher levels of group performance.

Groups may benefit from having leaders with a transformational style to foster knowledge creating and exploiting. However, the groups themselves need to be assigned to particular projects or parts of a larger project in order to achieve overall firm objectives. A transactional leadership style would be most effective in this process of coordination. Middlelevel managers work with team leaders to establish goals, rewards and specific project assignments. By coordinating efforts across several teams, transactional leaders facilitate the exploiting of knowledge created in other parts of the organization into new products and services. This leads to the following proposition.

Proposition 5: A transactional leadership style facilitates increases in knowledge exploitation in groups.

\section{Organizational Level}

Knowledge is transformed into a more systemic phenomenon at the organization level. Knowledge that was created and interpreted at the individual level and integrated at the group level is institutionalized at the organizational level (Crossan et al., 1999). Leadership at the organizational level includes all the members of the top management team (TMT) and other high level managers. The research on transformational leaders suggests that they are more effective and achieve higher organizational performance. Therefore, organizations may desire to have a transformational leader in the top position. However, TMTs may want to have an executive in charge of managing knowledge and learning.

Top managers who able to think systemically can establish knowledge systems that will effectively capture and share knowledge. Consequently, transactional leadership style may be more effective at this level. Inspiring personal interactions with employees is less important than creating information systems and knowledge systems that routinize actions, rules and procedures. Knowledge systems make ideas, solutions and knowledge created by others in the organization available to everyone in the organizations. Knowledge can then be exploited into new products, new customer solutions and improved practices. Organizations that are able to effectively make tacit knowledge explicit through their systems and exploit these ideas will create competitive advantages.

Transformational leaders inspire, provide a vision and intellectually stimulate their followers. However, they tend to be weaker on 
systems, structures and implementation. Transformational leaders require staffs that can supplement their weaknesses. CEOs will benefit from making knowledge management a central part of their jobs. CEOs provide the leadership for creating the information technology (IT) infrastructure as well as integrating it with the firms' strategies. CEOs will also benefit from encouraging and rewarding knowledge managing behaviors. Transformational leaders are able to provide the leadership necessary to create, share and exploit knowledge. However, transactional leaders create the systems and structures that allow knowledge and information to be efficiently shared throughout the organization. Transactional leaders provide the IT systems and structures that facilitate the sharing and exploiting of ideas. This leads to the following proposition:

Proposition 6: A transactional leadership style is associated with higher levels of knowledge exploitation at the organizational level.

Differences in knowledge processes at each level of the organization necessitate emphasizing different leadership styles at each level. Consequently, transformational and transactional leadership styles can coexist effectively in the same organization. Firms that rely primarily on creating knowledge for competitive advantage will emphasize transformational leadership. In these firms innovation and creativity are highly valued and essential for success. A large software firm would be more likely to emphasize transformational leadership, since innovation and creativity are highly valued. Software firms may utilize transformational leadership at the top and at lower levels in order to facilitate creativity and innovation. However, software firms also have transactional leaders at the organizational level who establish systems, structures and an IT infrastructure that efficiently captures knowledge (Stross, 1996).

Firms that focus more on keeping costs down rely more heavily on exploiting knowledge than creating and sharing it. Innovations are used primarily to make existing processes more efficient, rather than creating entirely new products and services. Southwest Airlines is an innovative company that focuses primarily on keeping costs down and quality consistently high. Their IT systems capture ideas that can be quickly converted into cost savings and increased efficiencies. For example, Southwest Airlines customers now book seventy percent of their tickets on the Internet (Donlon, 1999). This innovation is more efficient for the customers and much less expensive for Southwest Airlines, resulting in higher quality customer service and lower costs.

\section{Research Implications}

This paper lays a beginning foundation for evaluating the impact of leadership on knowledge creation, sharing and exploiting. Future researchers may want to introduce additional leadership styles as well as contextual variables and hypothesize about their impact on knowledge. The greatest need in this area is empirical testing of the organizational knowledge constructs. Researchers may want to explore the key links in this argument: 1) the link between organizational knowledge and individual, team and organizational performance; 2) the link between transformational leadership and managing knowledge at the individual and group levels; and finally 3) the link between transactional leadership and managing knowledge at the organizational level.

In order to test the connections between these constructs, researchers will have to operationalize them into measurable variables. Existing research may point the way on this front. Crossan \& Hulland (1997) and Bontis (1999) have designed self-report survey items that assess worker perceptions of knowledge managing behaviors. Bontis (1999) assessed the impact of knowledge stocks and flows on the performance of mutual fund companies in Canada and found a significant positive relationship between knowledge stocks and firm performance. His survey instrument appears to be valid and reliable at least in this context.

Bass and his colleagues (Bass, 1985; Yammarino, Spangler \& Bass, 1993) developed the Multifactor Leadership Questionnaire (MLQ) to assess transformational and transactional leadership styles based on the reports of employees. Several studies have assessed its validity and reliability and found that it is psychometrically solid (Den Hartog \& 
Van Muijen, 1997; Lowe, et al., 1996). Conger and Kanungo (1998) have developed a similar survey instrument that assesses the charismatic leadership style. The entire instrument or key items from the instrument could be used to assess leadership styles at different levels of organizations.

Several research designs could be used to address these questions. Researchers could use a survey to assess knowledge processes and leadership styles in firms within the software industry. Researchers could also use qualitative methods and spend time in the field observing teams and organizations, assessing knowledge creating, sharing and exploiting behaviors and leadership styles. Perhaps a combination of these methods would lead to stronger empirical findings.

Factoring in more contextual variables to the model could extend this line of research. Currently the model focuses primarily on internal organizational factors that affect knowledge processes. Variations among firms will also likely impact knowledge processes. A firm's strategy, particularly whether it pursues a low cost or a differentiation strategy will impact knowledge processes. We would also expect the organizational environment including type of industry, level of competition, government regulation and rate of change in technology to impact knowledge (Boisot, 1998). Future research can explore more deeply the connections between internal and external firm factors and how they impact knowledge processes. Finally, researchers may want to examine how external factors affect the need for transformational and transactional leaders in managing knowledge. Certain industries may have faster rates of technological change, higher levels of regulation and higher levels of competition. We would expect these factors to impact the effectiveness of organizations' leaders.

\section{Conclusion}

Strategy scholars have argued that managing knowledge effectively is critical to creating sustainable competitive advantages (Boisot, 1998; Teece, 1998). Leaders are central to the process of creating cultures, systems and structures that foster knowledge creation, sharing and cultivation. Transformational (Bass, 1985) and charismatic leadership theory (Conger \& Kanungo, 1998) offers promise as a foundation for managing organizational knowledge.

There are several implications for managers. First, managers can make their organizations more effective and create a competitive advantage by intentionally managing knowledge. Second, by using an appropriate blend of transformational and transactional leadership styles, managers can increase firms' levels of knowledge creating, sharing and exploiting. Third, managers that effectively manage knowledge will attract and retain better workers. Finally, firms that are able to better manage their knowledge assets will create sustainable competitive advantages. As the importance of knowledge assets continues to grow, firms will turn increasingly to their leaders to manage this valuable asset more effectively.

\section{References}

Barney, J. B. (1991). Firm resources and sustained competitive advantage. Journal of Management. 17: 99-120.

Barney, J. B. (1995). Looking inside for competitive advantage. The Academy of Management Executive. 4 (November): 49-61.

Bass, B. M. (1985). Leadership and performance beyond expectations. New York: Free Press.

Bass, B. M. (1990). Bass \& Stodgill's handbook of leadership: Theory, research and managerial applications. New York: Free Press.

Bass, B. M. \& Avolio, B. (1993). Transformational leadership: A response to critiques. In M. M. Chemers \& R. Ayman (Eds.), Leadership theory and research: Perspectives and directions. New York: Academic Press.

Bennis, W. \& Biederman, P. W. (1997). Organizing genius. Reading, MA: Addison-Wesley Publishing Co., Inc.

Boisot, M. H. (1998). Knowledge assets: Securing competitive advantage in the information economy. New York: Oxford University Press.

Bontis, N. (1999). Managing an organizational learning system by aligning stocks and flows of knowledge: An empirical examination of intellectual capital, knowledge management, and business performance. Dissertation: University of Western Ontario.

Brooking, A. (1996). Intellectual capital. New York: Thompson Business Press. 
Burns, J. M. (1978). Leadership. New York: Harper \& Row.

Conger, J. A. \& Kanungo, R. N. (1987). Toward a behavioral theory of charismatic leadership in organizational settings. Academy of Management Review. 12: 637-647.

Conger, J. A. \& Kanungo, R. N. (1998). Charismatic leadership in organizations. Thousand Oaks, CA: Sage.

Conger, J. A. (1999). Charismatic and transformational leadership in organizations: An insider's perspective on these developing streams of research. Leadership Quarterly. 10: 145-169.

Crossan, M. Lane, H. W., \& White, R. E. (1999). An organizational learning framework: From intuition to institution. Academy of Management Review. 24: 522-537.

Crossan, M. \& Hulland, J. (1997). Measuring organizational learning. Presentation at the Academy of Management Conference. Boston, MA.

Daft R. L. \& Lewin, A. Y. (1993). Where are the theories for the "new" organizational forms? An editorial essay. Organization Science. 4: i-vi.

Daft, R. L. \& Weick, K. E. (1984). Toward a model of organizations as interpretation systems. Academy of Management Review. 9: 284-295.

Davenport, T. \& Prusak, L. (1997). Information ecology: Mastering the information and knowledge environment. New York: Oxford University Press.

Den Hartog, N. \& Van Muijen, J. J. (1997). Transactional versus transformational leadership: An analysis of the MLQ. Journal of Occupational \& Organizational Psychology. 70: 19-35.

Dodgson, M. (1993). Organizational learning: A review of some literatures. Organization Studies. 14: 375-394.

Donlon, J. P. (1999). Air Herb's Secret Weapon. Chief Executive. July-August: 32-39.

Fiol, M. C., Harris, D. \& House, R. (1999). Charismatic leadership: Strategies for effecting social change. Leadership Quarterly. 10: 449482.

Glazer, R. (1998). Measuring the knower: Towards a theory of knowledge equity. California Management Review. 40: 175-195.

Goodwin, B. (1999). Cisco saves millions with staff intranet. Computer Weekly. May: 12.

Grant, R. (1996). Toward a knowledge-based theory of the firm. Strategic Management Journal. 17 (Winter Special Issue): 109-122.
Gronn, P. (1997). Leading for learning: Organizational transformation and the formation of leaders (The role of transformational leadership in organizational change). Journal of Management Development. 16: 274-283.

Hamel, G. \& Prahalad, C. K. (1994). Competing for the future. Boston: Harvard Business School Press.

Hedberg, B. L. (1981). Organizational learning. In P. Nystrom and W. Starbuck, Handbook of Organization Design. New York: Oxford University Press.

House, R. J. (1977). A 1976 theory of charismatic leadership. In J. G. Hunt \& L. L. Larson (Eds.). Leadership: The cutting edge. Carbondale: Southern Illinois University Press.

House, R. J. \& Aditya, R. N. (1997). The social scientific study of leadership: Quo vadis? Journal of Management. 23: 409 - 473.

House, R. J., Spangler, W. D., \& Woycke, J. (1991). Personality and charisma in the U.S. presidency: A psychological theory of leader effectiveness. Administrative Science Quarterly. 36: 364-396.

Hunt, J. G., \& Conger, J. A. (1999). From where we sit: An assessment of transformational and charismatic leadership research. Leadership Quarterly. 10: 335-343.

Keller, R. T. (1992). Transformational leadership and the performance of research and development project groups. Journal of Management. 18: 489-501.

Levinthal, D. \& March, J. (1993). The myopia of learning. Strategic Management Journal. 14: 95-122.

Lowe, J. (1998). Bill Gates speaks: Insight from the world's greatest entrepreneur. New York: John Wiley and Sons.

Lowe, K. B., Kroeck, K. G., \& Sivasubramaniam, N. (1996). Effectiveness correlates of transformational and transactional leadership: A meta-analytic review of the MLQ literature. Leadership Quarterly. 7: 385-425.

March, J. G. (1991). Exploration and exploitation in organizational learning. Organizational Science. 2: 71-87.

Miles, R. E., Snow, C. C., Matthews, J. A., Miles, G., \& Coleman, H. J. (1997). Organizing in the knowledge age: Anticipating the cellular form. Academy of Management Executive. 11: p 7-25.

Mumford, M. D., Whetzel, D. L., \& Reiter-Palmon, R. (1997). Thinking creatively at work: Organization influences on creative problem solving. Journal of Creative Behavior. 31: 7-17.

Nonaka, I. \& Takeuchi, H. (1995). The knowledgecreating company. New York: Oxford University Press. 
Penrose, E. T. (1959). The theory of the growt th of the firm. Oxford, England: Basil Blackwell.

Podsakoff, P. M., McKenzie, S. B. \& Bommer, W. H. (1996). Transformational leader behaviors and substitutes for leadership as determinants of employee satisfaction, commitment, trust and organizational citizenship behaviors. Journal of Management. 22: 259-298.

Poe, R. (2000). What price PARC? Business 2.0. December 12: 238-243.

Redmond, M. E., Mumford, M. D., \& Teach, R. (1993). Putting creativity to work: Effects of leader behavior on subordinate creativity. Organizational Behavior \& Human Decision Processes. 55: 120-151.

Sashkin, M. (1988). The visionary leader. In J. A. Conger \& R. N. Kanungo (Eds.). Charismatic Leadership: The elusive factor in organizational effectiveness. (pp. 122-160). San Francisco: Jossey-Bass.

Schumpeter, J. (1950). Capitalism, socialism and democracy. New York: Harper.

Senge, P. (1990a). The leader's new work: Building learning organizations. Sloan Management Review. 32 (Fall): 7-23.

Senge, P. (1990b). The fifth discipline. New York: Doubleday.

Sosik, J. J. (1997). Effects of transformational leadership and anonymity on idea generation in computer-mediated groups. Group \& Organization Management. 22: 460-479.
Starbuck, W. H. (1992). Learning by knowledgeintensive firms. Journal of Management Studies. 29: 713-740.

Stewart, T. A. (1997). Intellectual capital: The new wealth of organizations. New York: Doubleday.

Stross, R. E. (1996). The Microsoft way: The real story of how the company outsmarts its competition. Reading, MA: Addison-Wesley.

Teece, D. J. (1998). Capturing value from knowledge assets: The new economy, markets for knowhow, and intangible assets. California Management Review. 40: 55-79.

Wernerfelt, B. (1984). A resource-based view of the firm. Strategic Management Journal. 5: 171180.

Yammarino, F. J. \& Dubinsky, A. J. (1994). Transformational leadership theory: Using levels of analysis to determine boundary conditions. Personnel Psychology. 47: 787-811.

Yammarino, F. J. \& Spangler, W. D. (1998). Transformational and contingent reward leadership: Individual, dyad, and group levels of analysis. Leadership Quarterly. 9: 27-54.

Yammarino, F. J., Spangler, W. D. \& Bass, B. M. (1993). Transformational leadership and performance: A longitudinal investigation. Leadership Quarterly. 4: 81-102.

Yukl, G. \& Howell, J. M. (1999). Organizational and contextual influences on the emergence and effectiveness of charismatic leadership. Leadership Quarterly. 10: 257-283. 